\title{
Shell growth of Astarte elliptica (Bivalvia) from Kiel Bay (Western Baltic Sea)
}

\author{
K. Trutschler ${ }^{1 *}$, C. Samtleben ${ }^{2}$ \\ ${ }^{1}$ Institut für Meereskunde, Düsternbrooker Weg 20, D-2300 Kiel, Federal Republic of Germany \\ ${ }^{2}$ Institut für Geologie und Paläontologie und Museum, Ohlshausenstraße 40-60, D-2300 Kiel, Federal Republic of Germany
}

\begin{abstract}
Information on growth and age of Astarte elliptica (Brown, 1827), a common bivalve in muddy sand sediments in Kiel Bay below $15 \mathrm{~m}$ water depth, is scattered and inconclusive. Unchanged size-frequency distributions from October 1984 to September 1985 at the 'Suderfahrt' sampling station, $21 \mathrm{~m}$ water depth, suggest very slow growth. There was no linear correlation between the distinct concentric external shell ridges and internal shell growth bands. Internal growth bands were counted from acetate peels of sections of the tooth region examined by scanning electron microscopy. Evidence for an annual periodicity of growth band formation is discussed. A life span of about $20 \mathrm{yr}$ is deduced for A. elliptica in Kiel Bay.
\end{abstract}

\section{INTRODUCTION}

Growth and production of benthic invertebrates have been studied as part of the energy flow through the ecosystem and with regard to their influence on the demersal fish stocks of Kiel Bay (e.g. Arntz 1970, 1971, 1977, 1980, Arntz \& Brunswig 1975, Samtleben 1977. Brey 1984, 1986, Schaefer et al. 1985). To calculate production of benthic invertebrates it is necessary to know their growth rates and age compositions.

Astarte elliptica (Brown, 1827) is a common bivalve in Kiel Bay in muddy sand sediments below $15 \mathrm{~m}$ water depth (Kühlmorgen-Hille 1963), which reachs high biomass values. There is a lack of well-founded knowledge about its growth rates and longevity; available information is scattered and inconclusive.

Jaeckel (1952) assumed a maximum age of more than 2 yr. The quantitative investigation carried out by Kühlmorgen-Hille (1963) showed that no conclusions about growth and age of Astarte species could be derived from size-frequency distributions, because the size composition of the populations seemed to remain unchanged during the whole year of study. Such constant size-frequency distributions point to a very slow growth of the species. Erlenkeuser et al. (1975) sug-

\footnotetext{
- Present address: Institut für Medizinische Strahlenkunde, Versbacherstraße 5, D-8700 Würzburg, Federal Republic of Germany
}

gested a possible life span of more than 10 yr for $A$. elliptica in Kiel Bay, based on determination of shell ${ }^{14} \mathrm{C}$-activity in some larger specimens.

The aim of the present paper is to determine the maximum age and thereby to obtain information on growth of Astarte elliptica in Kiel Bay.

As the hydrography of Kiel Bay shows distinct seasonal variations (e.g. in temperature, oxygen content, salinity: Rumohr 1979; sedimentating phytoplankton blooms: Smetacek 1985, Graf 1987) one may also expect seasonal variations in the growth pattern of Astarte elliptica. The seasonal growth variations may result in visible growth marks on the external shell surface as has been shown for various bivalves, e.g. Orton (1926), Haskin (1954), Craig \& Hallam (1963), Theisen (1973). Such external patterns are present in A. elliptica in form of very distinct concentric ridges on the external shell surface (Fig. 1). It is however not clear whether these ridges are formed periodically and thus can be used for age determinations. Internal growth bands previously have been used for age determination of pluriannual organisms and for the reconstruction of the time course of past events, once their periodicity was established (Lutz 1976, Jones et al. 1978, Jones et al. 1983) and are here described for $A$. elliptica, together with results of a laboratory growth experiment. We define growth bands as zones of different structure alternating with shell increments and corresponding to periods of reduced growth (Dillon \& Clark 1980). 


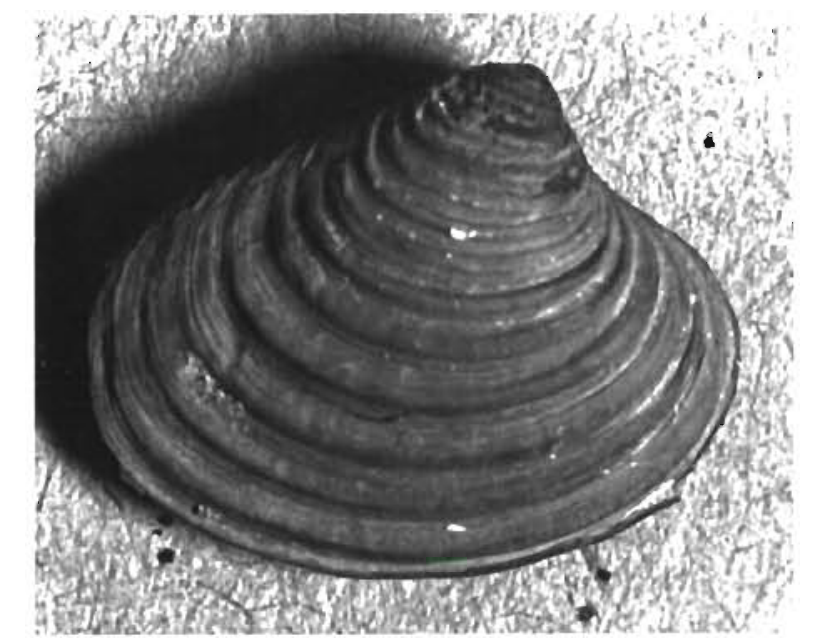

Fig. 1. Astarte elliptica. External shell ridges of a $12.8 \mathrm{~mm}$ long individual collected on 24 Apr 1985 at 'Suiderfahrt'

\section{MATERIALS AND METHODS}

Sampling took place at about monthly intervals from October 1984 to September 1985 at the 'Süderfahrt' station in the eastern part of Kiel Bay, where muddy sand sediment prevails, in $21 \mathrm{~m}$ water depth. At each sampling date ten $0.1 \mathrm{~m}^{2}$ Van-Veen grab samples were taken. Additional shell material from this station was dredged in April 1985. Grab and dredge material was passed through $1 \mathrm{~mm}$ sieves and fixed in $4 \%$ boraxbuffered formaldehyde. Shell length of Astarte elliptica was measured to the lower $0.1 \mathrm{~mm}$ with a sliding gauge.

In order to define the relationship between external shell ridges and shell growth, the ridges of 79 individuals collected in April 1985 were counted and plotted against shell length. The distances between successive ridges were determined by making imprints of the external shell surface of 3 individuals. The distances were measured with a stereo-microscope at 64-fold magnification.

From the 79 Astarte elliptica individuals investigated for shell ridges, 49 individuals of different sizes were used for study of internal growth bands in the shell. Shell length ranged from 3.0 to $28.6 \mathrm{~mm}$. The prominent cardinal tooth of the right valve was chosen for examination. Previous investigations have shown that growth structures are also clearly visible in parts other than the valve, i.e. the chondrophore of Spisula solidissima (Jones et al. 1978), the teeth of Venus striatula (Guillou \& Sauriau 1985) and the hinge plate of Arctica islandica (Thompson et al. 1980). Destructive environmental impacts have a less pronounced influence on the more protected hinge region than on the exposed valve, where growth bands tend to fan out and additional bands can appear (Ropes 1982).

The right valves were first embedded in resin for stabilisation and each valve was cut from the umbo to the ventral margin (Fig. 2) along the axis of maximum

dorsal

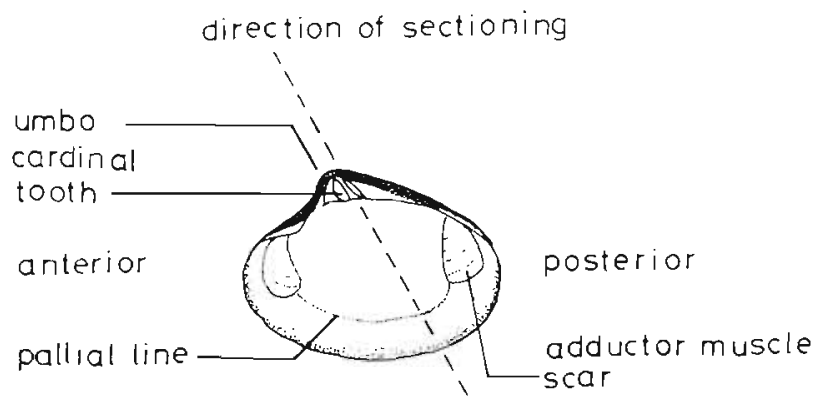

ventral

Fig. 2. Astarte elliptica. Internal features of the right valve with the direction of sectioning (broken line)

growth as described by Kennish et al. (1980) and Ropes (1982). After grinding and polishing, the shell sections were studied for growth patterns under a stereo-microscope. The preparation of acetate peels followed the procedure described by Kennish et al. (1980), but with the modification of etching with a $1 \% \mathrm{HCl}$ solution for $15 \mathrm{~s}$.

For examination of the ultrastructure, acetate peels were made of the shell sections from 2 individuals of $20.5 \mathrm{~mm}$ shell length collected in April 1985. The polished and etched shell slices were coated with carbon and gold/palladium under vacuum and examined under a Cambridge S-150-scanning electron microscope (SEM) operated at $20 \mathrm{kV}$ Growth bands visible on photographs of the acetate peels of both individuals were counted and the corresponding crystal arrangements identified on scanning electron micrographs of the coated shell sections. The distances between identified successive growth bands were measured from scanning electron micrographs at 500-fold magnification.

Individuals of Astarte elliptica dredged in May 1985 from the 'Mittelgrund' station (16 m. water depth) in the western part of Kiel Bay were first measured and then transplanted into boxes with macrofauna-free habitat sediment and kept at $10^{\circ} \mathrm{C}$ in the laboratory. Cuitures of the green alga Nannochloris sp., which tolerates brackish water conditions (Witt et al. 1981), were used as food. The aquarium was kept dark to establish conditions as natural as possible. Water was exchanged monthly. Control of $\mathrm{pH}_{1}$ nitrite and ammonia concen- 
trations exhibited only minor deviations from natural conditions. The experiment was started on 24 May 1985 and lasted until 3 Oct 1985. At the end of the experiment the final shell length of the individuals was measured.

\section{RESULTS}

\section{Size structure}

A total of 1720 Astarte elliptica individuals were caught on 10 occasions between October 1984 and September 1985. The abundance varied between 54 ind $\mathrm{m}^{-2}$ in September 1985 and 350 ind $\mathrm{m}^{-2}$ in April 1985, with a mean value of 172 ind $\mathrm{m}^{-2}$ (Fig. 3). With

Number of individuals

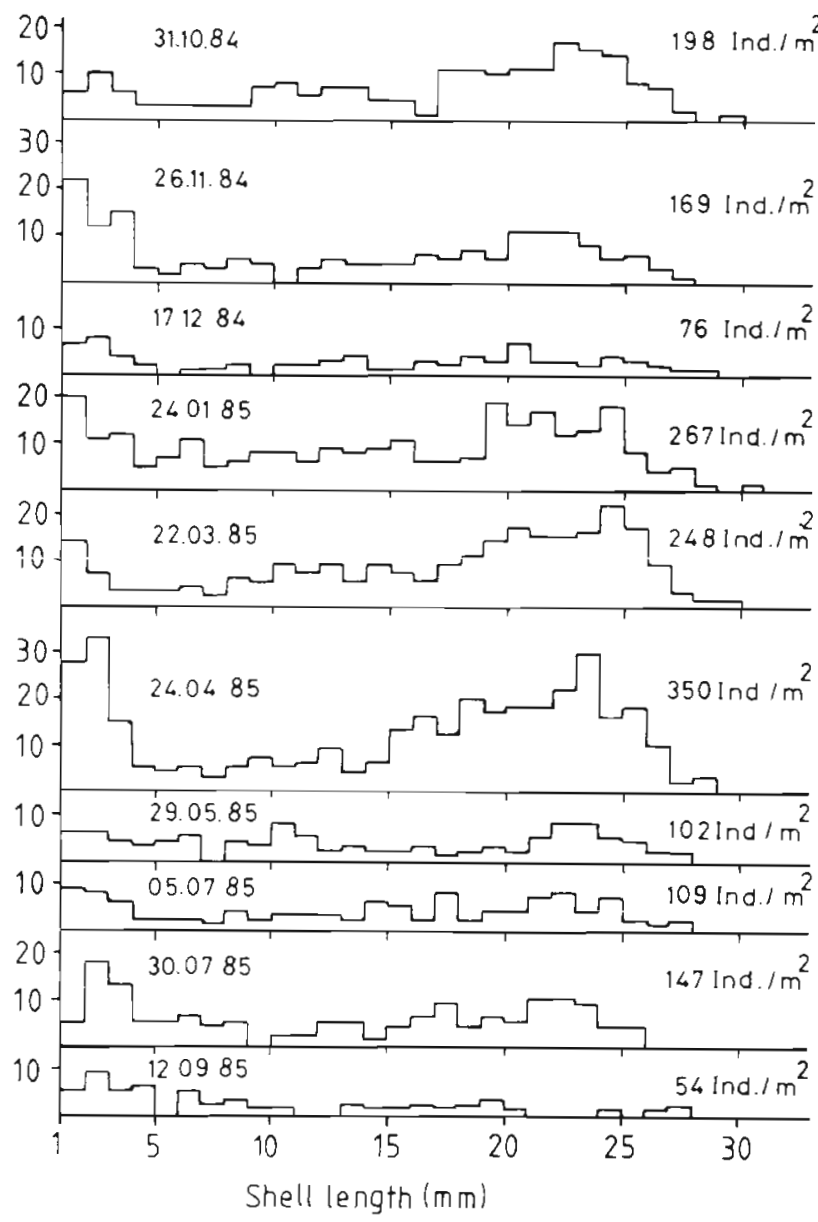

Fig. 3. Astarte elliptica. Size-frequency histograms of shell length from grab samples at 'Süderfahrt'

the exception of September 1985 the samples show nearly identical bimodal size-frequency distributions characterized by a high number of 1 to $4 \mathrm{~mm}$ long individuals and a considerably larger group of 16 to 25 $\mathrm{mm}$ long individuals. The maximum shell length meas- ured in the samples was $31.4 \mathrm{~mm}$. The nearly constant size-frequency distributions suggest very slow shell growth of the species during the time of investigation. If recruitment is annual, the larger individuals making up the right-hand mode are likely to include several age groups of the population.

\section{Growth experiment}

Increase in shell length during the laboratory growth experiment from May to October was very low for all individuals. A maximum increase of $1.4 \mathrm{~mm} \mathrm{yr}^{-1}$ was calculated for small individuals with a shell length up to $5 \mathrm{~mm}$, and of $0.6 \mathrm{~mm} \mathrm{yr}^{-1}$ for large individuals with a shell length $>15 \mathrm{~mm}$, on the basis of a $132 \mathrm{~d}$ experiment (Table 1).

Table 1. Astarte elliptica. Maximum shell growth in aquaria at $10^{\circ} \mathrm{C}$. Food was Nannochloris sp.

\begin{tabular}{|ccc|}
\hline $\begin{array}{c}\text { Shell length } \\
(\mathrm{mm})\end{array}$ & $\mathrm{n}$ & $\begin{array}{c}\text { Maximum increase } \\
(\mathrm{mm} \text { in 132 d) }\end{array}$ \\
\hline below 5.0 & 11 & 0.5 \\
$5.0-9.9$ & 8 & 0.3 \\
$10.0-14.9$ & 1 & 0.3 \\
$15.0-19.9$ & 3 & 0.2 \\
$20.0-24.9$ & 1 & 0.2 \\
\hline
\end{tabular}

\section{External shell ridges}

The number of external shell ridges of 79 Astarte elliptica individuals sampled in April 1985 was counted and plotted against shell length (Fig. 4). A significant linear relation represented by the equation $\mathrm{y}=$ $10.63+0.72 \times(r=0.913, \mathrm{n}=79, \mathrm{p} \leq 0.001)$ was obtained. Deviations from the calculated regression line are spread over the whole range of measurements more or less equally. They are probably caused by difficulties in discerning the initial ridges in the umbonal area. In most specimens this area was covered with a manganese concretion. Removing this concretion generally resulted in the destruction of some ridges so that they could not be counted.

In spite of this uncertainty, ridges are numbered from the umbo to the ventral margin. In 3 individuals $\{20.7$ to $26.4 \mathrm{~mm}$ shell length) the distance between successive ridges was measured. The distances increase in the first set of about 12 ridges, with a strong linear relation (Fig. 5). The coefficients of slope were not significantly different ( $p \leq 0.05$, tested after Sachs 1984) in the 3 individuals. Peripherally, ridges are more prominent; their distances are equal between the 5 th and 7 th 


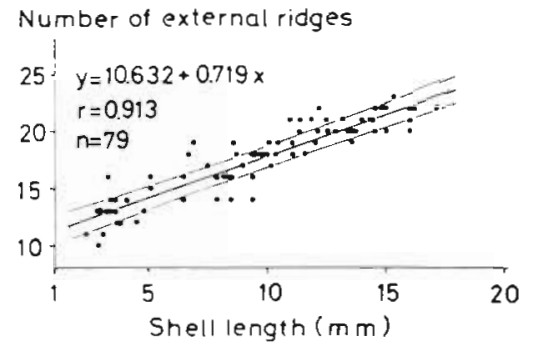

Fig. 4. Astarte elliptica. Correlation of shell length with number of external shell ridges of 79 individuals from 'Süderfahrt'; 24 Apr 1985. Calculated regression line and corresponding $95 \%$ confidence limits

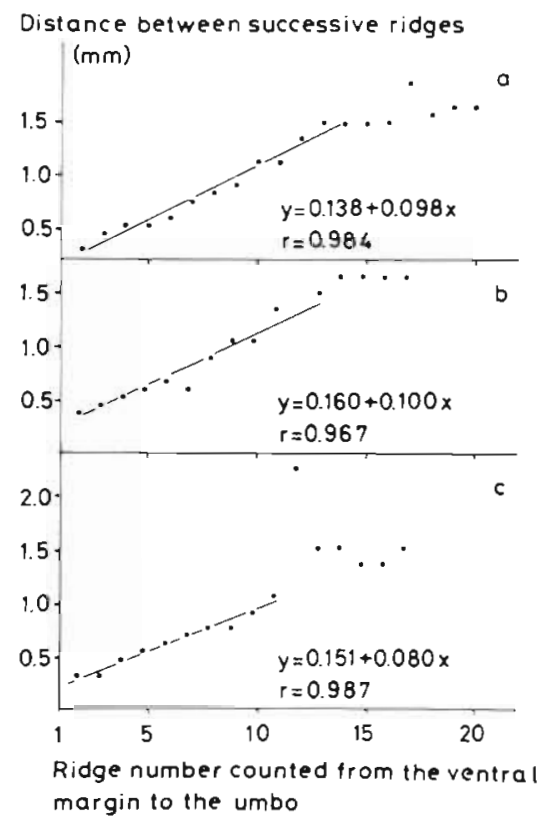

Fig. 5. Astarte elliptica. Plot of external ridges against the distance between successive ridges of 3 individuals with shell lengths (a) $26.4 \mathrm{~mm}$, (b) $20.9 \mathrm{~mm}$, and (c) $20.7 \mathrm{~mm}$, from

'Süderfahrt', 24 Apr 1985. Calculated regression lines

peripheral ridges. This means that in older individuals the concentric external shell ridges are formed according to the pattern of the shell sculpture characteristic for the species Astarte elliptica (Fig. 1), independent of allometric growth.

\section{Internal growth bands}

A further argument supporting the idea that external shell ridges, at least the peripheral ones, are not strictly related to age is provided by the investigation of internal growth bands within the shell. It was not possible to trace the growth bands from the tooth region to the outer shell surface in shell sections (Fig. 6) because the

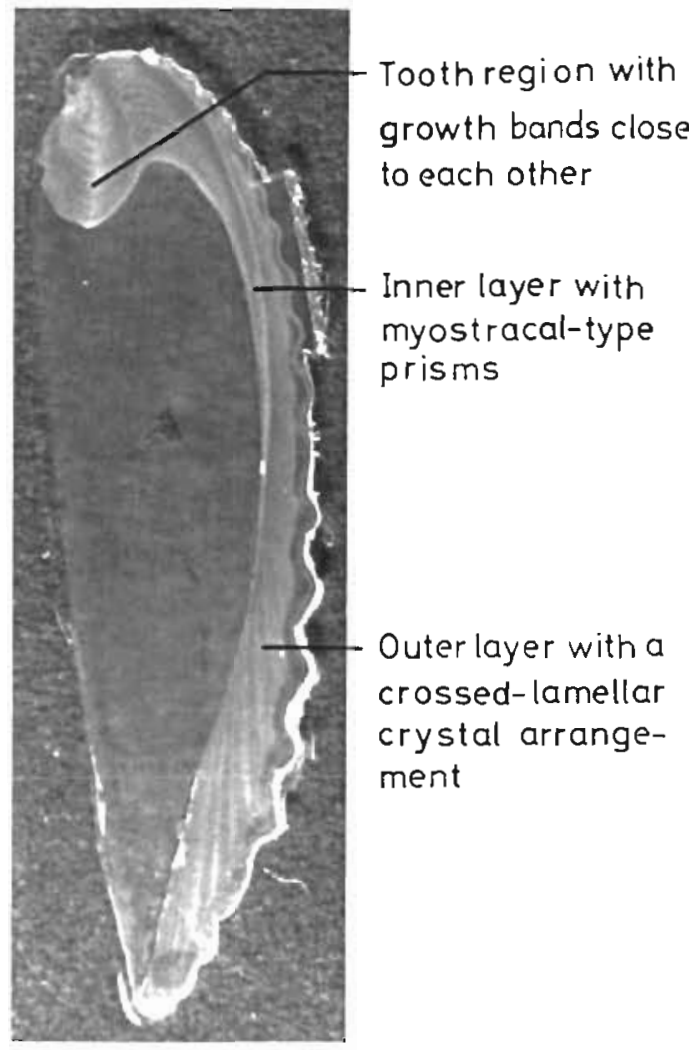

Fig. 6. Astarte elliptica. Acetate peel of the radial shell section of the right valve of an individual with a shell length of 25.3 mm, collected on 24 Apr 1985 at 'Süderfahrt

inner layer is built up of myostracal prisms (Taylor et al. 1973). However, in acetate peels of the valves of larger individuals ( $>20 \mathrm{~mm}$ shell length), it was possible to discern assemblages of darker bands which should correspond to growth bands. Only in the middle part of the valve do these darker bands seem to terminate in the external ridges, otherwise they terminate irregularly either in a ridge or between 2 ridges. Close to the ventral margin, it sometimes appears that more than one band terminates in a ridge. Assuming annual formation of growth bands, this means that it takes several years to form a peripheral external shell ridge.

Under the stereo-microscope all of the studied polished and etched shell sections of Astarte elliptica showed a pattern of banding. Opaque bands alternate with somewhat darker translucent bands that are clearly visible in the tooth region (Fig. 7). Discriminating the bands in the tooth region became more difficult as the number of bands increased in larger valves. This problem was overcome by using acetate peels of the shell sections. Bright growth bands were recognizable contrasting with the darker colour of the growth increments as shown in Fig. 8.

The enumeration of growth bands was complicated by the varying strength and structure of the bands; 


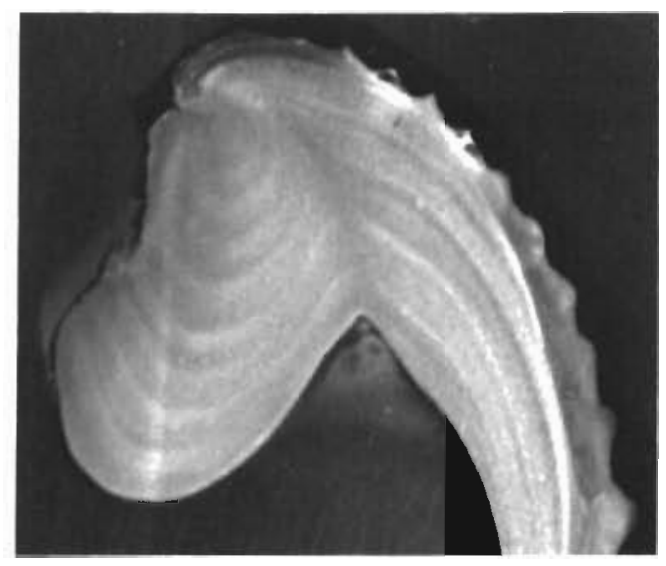

Fig. 7. Astarte elliptica. Polished and etched shell section with growth pattern visible in the tooth region of a $14.0 \mathrm{~mm}$ long individual collected on 24 Apr 1985 at 'Süderfahrt'

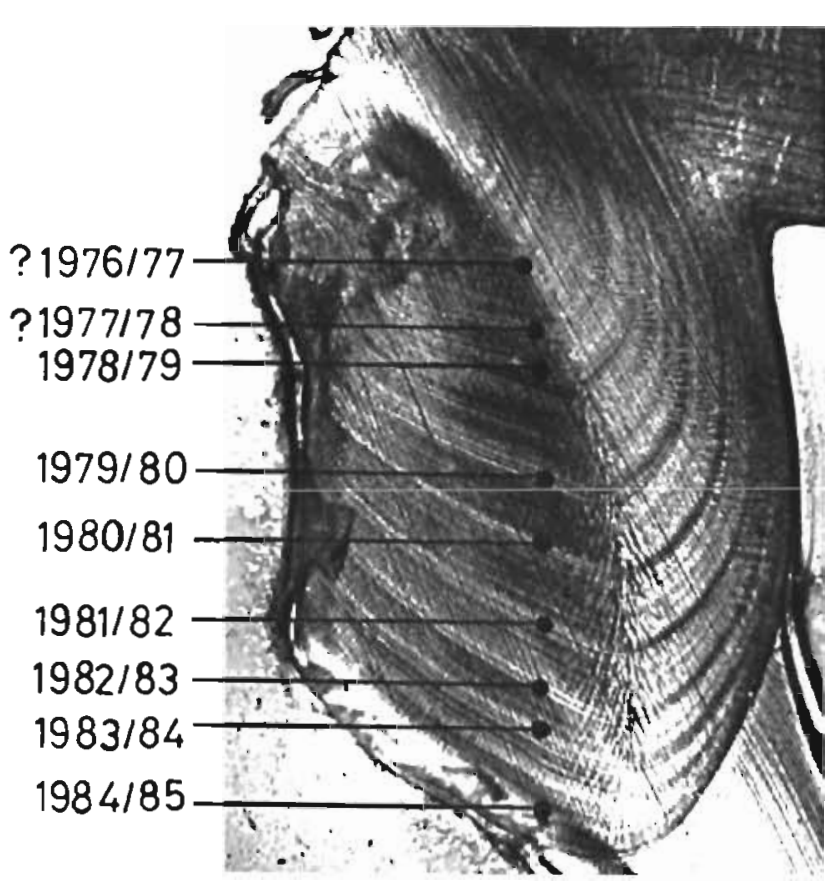

Fig. 8. Astarte elliptica. Acetate peel of the tooth region (right valve) of a $20.5 \mathrm{~mm}$ long individual collected on 24 Apr 1985 from 'Süderfahrt'. The growth bands are numbered with the year when they were probably secreted, assuming annual formation

some being bold and prominent in between finer bands. Fig. 8 shows 11 growth bands and the hypothetical years of secretion under the assumption that they are formed annually. The black and white print of the acetate peel was taken with crossed nicols, which results in a better contrast between growth bands and increments, facilitating counting procedures.

In almost all of the studied shell sections parts of the umbo were lacking, which was probably caused by mechanical forces or by dissolution removing one or more of the earliest lines.

\section{Ultrastructure of growth bands}

The crystal arrangements which compose the growth bands visible on the acetate peel of a $20.5 \mathrm{~mm}$ long individual (see Fig. 8) were also examined by SEM. Micrographs of a section of the etched tooth region show the crossed-lamellar arrangement of the crystals which is interrupted by lines of somewhat larger granular prisms (Fig. 9a) and lines of larger prisms which are oriented with their long axis parallel to the growth direction in the tooth region (Fig. 9b).

Fig. 10 shows the sequence of crystal arrangements in a profile through the tooth. The hypothetical years of secretion $1974 / 75$ to $1984 / 85$ are given. Each year from 1975 onwards encloses several lines which together form the growth bands distinguishable on the acetate peels (see Fig. 8). The corresponding bands on the SEM-micrograph of the whole tooth region are indicated in Fig. 11.

\section{Growth band discrimination}

Erosion of the shell in the umbonal area affects the hinge region, too, so that bands in the oldest parts of the tooth are difficult to discriminate. The question marks regarding the years of secretion shown in Fig. 10 reflect this uncertainty. Bands with larger prisms, oriented with their long axis parallel to the growth direction in the tooth appear only in the middle of the tooth profile (VP in Fig. 10: 1979/80, 1980/81, 1981/82, $1982 / 83)$. Bands of smaller and granular prisms, some of them $\left(G P_{H}\right.$ in Fig. 10) more evident than others (GP) form the remaining growth bands identified on the acetate peel.

In the tooth region of the second $20.5 \mathrm{~mm}$ long individual, which was studied by SEM, 11 growth bands could be enumerated as in the individual of Figs. 8 to 11 . The identification of growth bands in the proximal part of the tooth was also difficult, because of erosion of this area. The tooth region of this specimen showed only slight deviations in the crystal arrangements of the growth bands in comparison to the tooth profile documented in Fig. 10

The distances between successive growth bands in the tooth regions of both individuals showed a slight decrease from the umbo toward the distal part of the tooth. However, there was some variation especially between those bands marked with question marks (bands that were difficult to identify) in the umbonal areas (Fig. 12). 

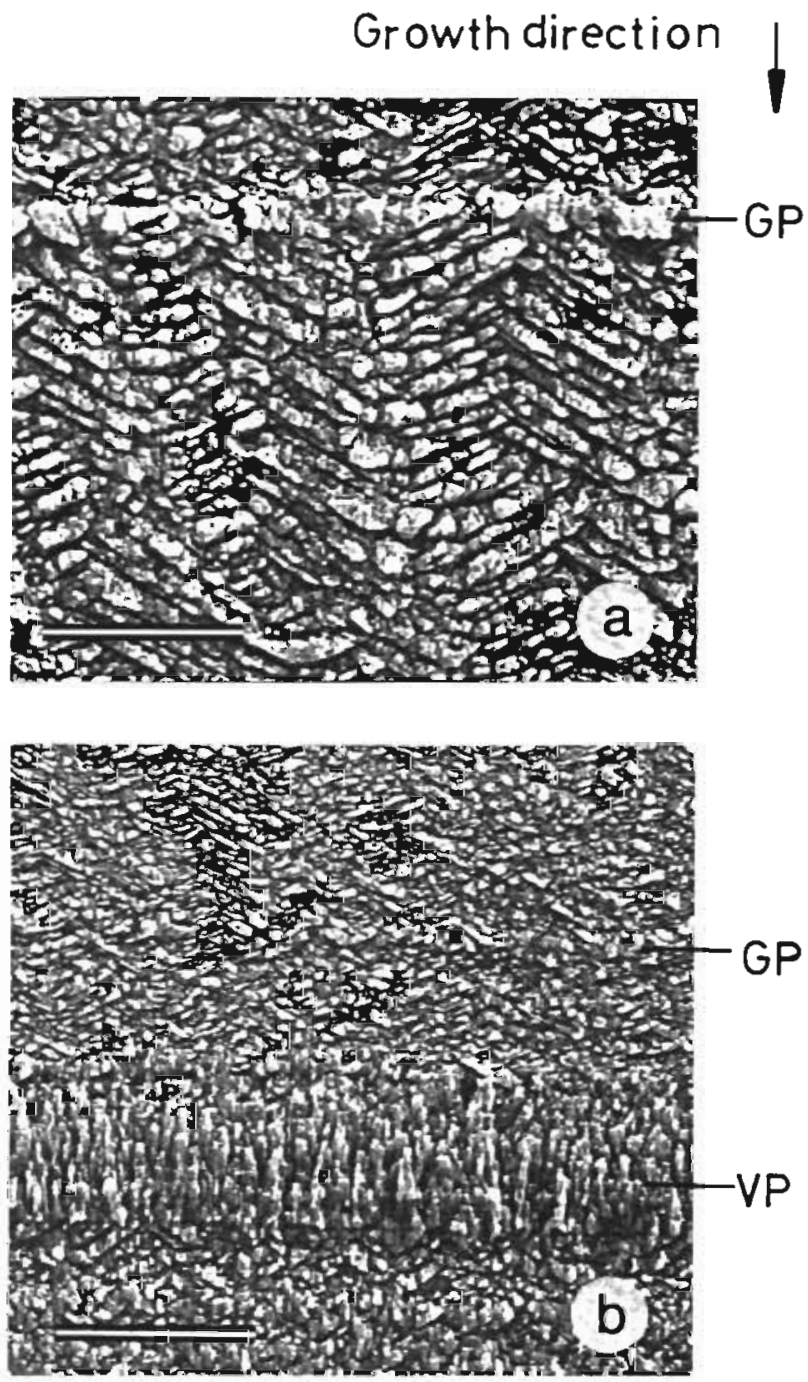

Fig. 9. Astarte elliptica. Scanning electron micrographs of a section of the tooth region representing the crossed-lamellar crystal arrangement. (a) In the upper part note line of granular prisms (GP); scale bar $=10$ um. (b) Note line of granular prisms and a layer of larger prisms, oriented with their long axis parallel to the growth direction in the tooth; scale bar = $20 \mu \mathrm{m}$. Direction of growth is shown by the arrow. Same shell as in Fig. 8

\section{DISCUSSION}

The size-frequency histograms, the growth experiment, and the ${ }^{14} \mathrm{C}$-analysis of some shells up to a length of about $28 \mathrm{~mm}$ by Erlenkeuser et al. (1975, p. 286: 'must be attributed to long life span of the bivalves that should markedly exceed 10 years'), suggest that Astarte elliptica is a very slow-growing species. Therefore we assume that the internal marks in the shells are annually secreted growth bands. The conclusion is that A. elliptica can attain a maximum age of about $20 \mathrm{yr}$.

According to Wada (1961) larger crystals are formed during periods of slow growth. In the present study

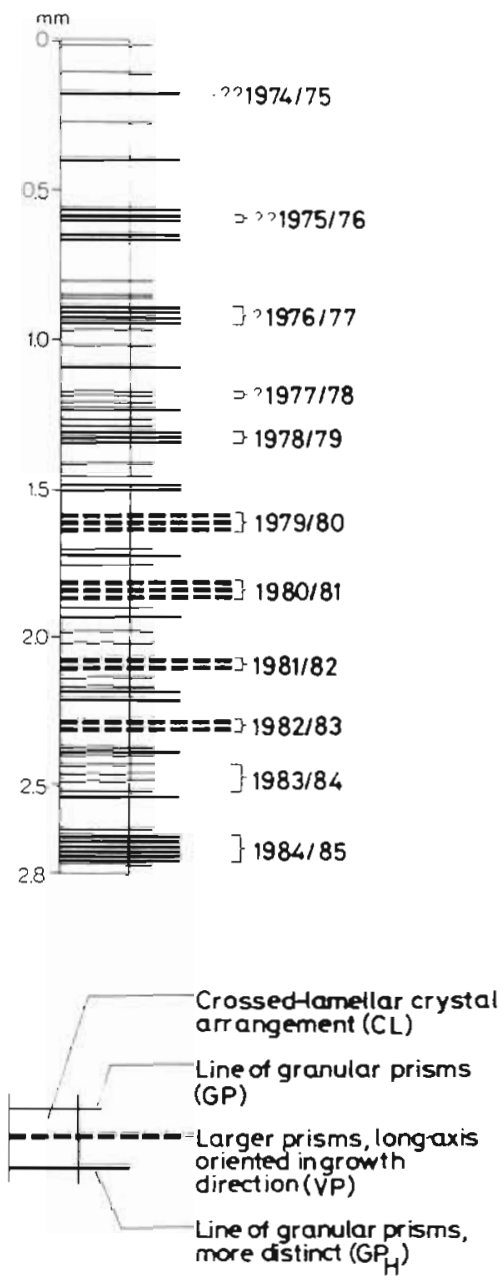

Fig. 10. Astarte elliptica. Sequence of crystal arrangements identified from SEM-micrographs of the tooth region of a 20.5 $\mathrm{mm}$ long individual (the same as in Fig. 8) represented in form. of a diagram. The groups of lines of prisms which compose the growth bands visible on the acetate peel (see Fig. 8) are numbered by the hypothetical years of secretion. The question marks indicate the uncertainties in relating crystal arrangements to growth bands in the oldest (upper) part of the tooth

larger crystals were observed in the internal growth bands, whereas the increments consisted of small crystals. These findings lead to the conclusion that internal growth bands were formed during periods of slow growth and the increments represent periods of normal growth. The distances between the bands decrease from the umbo towards the distal part of the tooth. However, the decrease is not very distinct. Nevertheless it can be inferred that shell growth in the first years of life was faster than in later years. This conclusion is supported by the larger growth increments measured after $132 \mathrm{~d}$ of growth under laboratory conditions in small than in large individuals, indicating that growth is asymptotic.

In Kiel Bay, bottom water temperatures show a dis- 


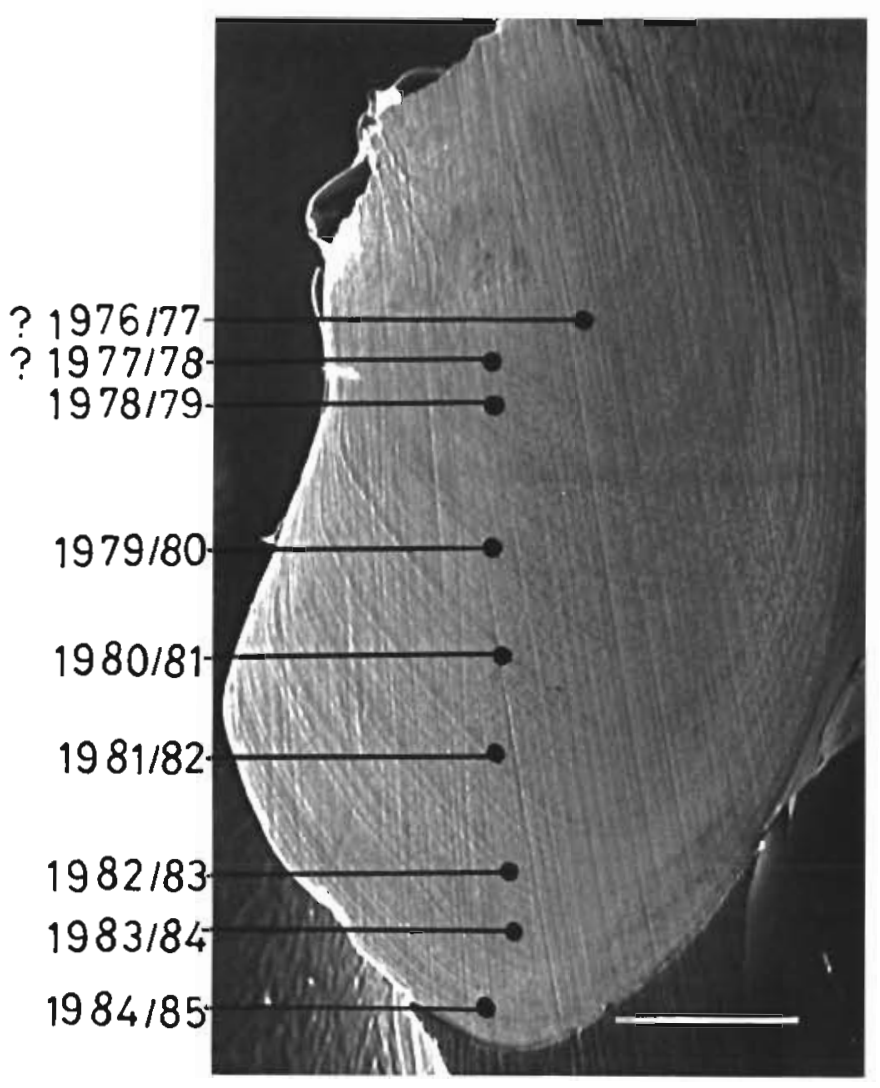

Fig. 11. Astarte elliptica. SEM-micrograph of the whole tooth region of a $20.5 \mathrm{~mm}$ long individual (same as in Figs. 8 to 10). The growth bands are numbered with the hypothetical year of secretion. Scale bar $=0.5 \mathrm{~mm}$

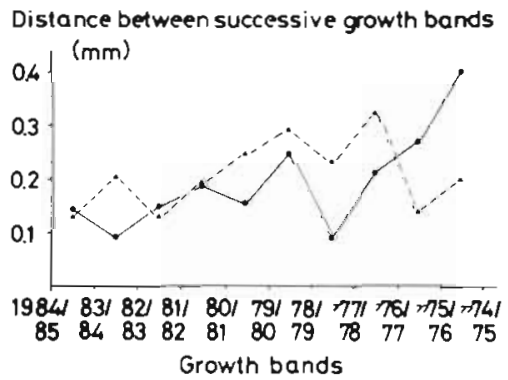

Fig. 12. Astarte elliptica. Plot of number of growth bands (hypothetical year of formation) against the distance between every 2 growth bands in the tooth region of 2 individuals from 'Süderfahrt', 24 Apr 1985, both with a shell length of $20.5 \mathrm{~mm}$

tinct seasonality at $20 \mathrm{~m}$ depth with maximum temperatures of about $14^{\circ} \mathrm{C}$ in September decreasing to about $1{ }^{\circ} \mathrm{C}$ in March (Rumohr 1979). Low winter temperatures are an important periodical factor in slowing down growth (Craig \& Hallam 1963, Clark 1974). Food supply too, has annual seasonality: it is high from April (settlement of the spring phytoplankton bloom) to the end of October (autumn blooms), and low in winter.
Both these factors suggest that growth should be high in summer and low in winter. Thus it can be assumed that annual seasons trigger growth band formation in the shell of Astarte elliptica in Kiel Bay.

Situations of extreme oxygen depletion below the summer halocline in Kiel Bay (Ehrhardt \& Wenck 1984 Weigelt \& Rumohr 1986) last only up to several weeks and are probably not responsible for the secretion of growth bands in Astarte elliptica. This species, occurring in poorly oxygenated soft sediments, exhibits especially high tolerance to temporary oxygen deficiency (Dries \& Theede 1974). Another possibility is that spawning could trigger the secretion of growth bands in the shell, as shown for e.g. Spisula solidissima (Jones et al. 1978) and Arctica islandica (Thompson et al. 1980j. However Astarte-populations in the Baltic, as shown by Oertzen (1972), do not have a defined spawning season, so that it seems improbable that spawning has a great influence on growth band formation, although we cannot exclude that individuals of Astarte have distinct spawning events which influence growth. Further research is necesssary to corroborate our assumption that growth band formation is annual, but at present it seems that this is the most probable assumption.

Acknowledgements. We thank Prof. S. Gerlach for his support of this study and 3 anonymous reviewers for their helpful critism of the manuscript. We are also indebted to T. Brey, Dr H. Rumohr, Dr W. Stotz und M. Weigelt for their collaboration We thank Dr D. Barthel for correcting the English manuscript

\section{LITERATURE CITED}

Arntz, W E. (1970). Das Makrobenthos der Kieler Bucht im Jahr 1968 und seine Ausnutzung durch die Kliesche (Limanda limanda L.). Ph. D. thesis, Univ. of Kiel

Arntz, W E. (1971). Biomasse und Produktion des Makrozoobenthos in den tieferen Teilen der Kieler Bucht im Jahre 1968. Kieler Meeresforsch. 27: 36-72

Anntz, W. E. (1977). The food of the adult cod (Gadus morhua L.) in the Western Baltic. Meeresforschung 26: 60-69

Arntz, W. E. (1980). Predation by demersal fish and its impact on the dynamics of macrobenthos. In: Tenore, K., Coull, B. C. (eds.) Marine benthic dynamics. Univ. of South Carolina Press, Columbia, p. 121-149

Arntz, W. E., Brunswig, D. (1975). An approach to estimate the production of macrobenthos and demersal fish in a Western Baltic Abra alba community. Havsforskn. Skr. 239: 195-205

Brey, T (1984). Gemeinschaftstrukturen, Abundanz, Biomasse und Produktion des Makrozoobenthos sandiger Böden der Kieler Bucht in 5-15 m Wassertiefe. Ber. Inst. Meeresk. Univ. Kiel 123: 1-124

Brey, T. (1986). Increase in macrozoobenthos above the halocline in Kiel Bay comparing the 1960s with the 1980s. Mar. Ecol. Prog. Ser. 28: 299-302

Clark, G. R. (1974). Growth lines in invertebrate skeletons. Ann. Rev. Earth Planet. Sci. 2: 77-99

Craig, G. Y., Hallam, A. (1963). Size frequency and growth ring 
analysis of Mytilus edulis and Cardium edule, and their paleoecological significance. Paleontology 6: 731-750

Dillon, J. F.. Clark II, G. R. (1980). Growth line analysis as a test for contemporaneity in populations. In: Rhoads, D. C., Lutz, R. A. (eds.) Skeletal growth of aquatic organisms. Plenum Press, New York, p. $395-415$

Dries, R.-R., Theede, H. (1974). Sauerstoffmangelresistenz mariner Bodenevertebraten aus der Westlichen Ostsee. Mar. Biol. 25: 327-333

Ehrhardt, M., Wenck, A. (1984). Wind pattern and hydrogen sulfide in shallow waters of the Western Baltic Sea, a cause and effect relationship? Meeresforschung 30: 101-110

Erlenkeuser, H., Metzner, H., Willkomm, H. (1975). University of Kiel radiocarbon measurements VIII. Radiocarbon 17: $276-300$

Guillou, J., Sauriau, P. G. (1985). Some observations on the biology and the ecology of a Venus striatula population in the Bay of Douarnenez, Brittany. J. mar, biol. Ass. U. K. 65 889-900

Graf, G. (1987). Benthic response to the annual sedimentation pattern. In: Rumohr, J., Walger, E., Zeitzschel, B. (eds.) Seawater-sediment interactions in coastal waters. An interdisciplinary approach. Lecture notes on coastal and estuarine studies, Vol. 13. Springer-Verlag, Berlin, p. 84-92

Haskin, H. H. (1954). Age determination in mollusks. Trans. N. Y. Acad. Sci. 16: 300-304

Jaeckel, S. (1952). Zur Ökologie der Molluskenfauna in der Westlichen Ostsee. Schr. Naturw. Ver. Schlesw.-Holst. 26: $18-50$

Jones, D. S., Thompson, I., Ambrose, W (1978). Age and growth rate determinations for the Atlantic surf clam Spisula solidissima (Bivalvia: Mactracea), based on internal growth lines in shell cross-sections. Mar. Biol. 47: 63-70

Jones, D. S., Williams, D. F., Arthur, M. A. (1983). Growth history and ecology of the Atlantic surf clam, Spisula solidissima (Dillwyn), as revealed by stable isotopes and annual shell increments. J. exp. mar. Biol. Ecol. 73: 225-242

Kennish, M. J., Lutz, R. A., Rhoads, D. C. (1980). Preparation of acetate peels and fractured sections for observation of growth patterns within the bivalve shell. In: Rhoads, D. C., Lutz, R. A. (eds.) Skeletal growth of aquatic organisms. Plenum Press, New York, p. 597-601

Kühlmorgen-Hille, G. (1963). Quantitative Untersuchungen der Bodenfauna in der Kieler Bucht und ihre jahreszeitlichen Veränderungen. Kieler Meeresforsch. 19: 42-66
Lutz, R. A. (1976). Annual growth patterns in the inner shell layer of Mytilus eduitis L.. J. mar. biol. Ass. U. K. 56 $723-731$

Oertzen, J.-A. von (1972). Cycles and rates of reproduction of six Baltic Sea bivalves of different zoogeographical origin. Mar. Biol. 14: 143-149

Orton, J. H. (1926). On the rate of growth of Cardium edule. I Experimental observations. J. mar. biol. Ass. U. K. 14 $239-279$

Ropes, J. W. (1982). Procedures for preparing acetate peels of embedded valves of Arctica islandica for aging. U. S. Dept Comm., NOAA, NMFS, Woods Hole Lab., Doc. 82-18

Rumohr, H. (1979). Hydrographische Dauerregistrierungen bei Boknis Eck $(20 \mathrm{~m})$. Westliche Ostsee von 1975-1978. Rep. Sonderforschungsbereich 95, Univ. Kiel, 42: 1-59

Sachs, L. (1984). Angewandte Statistik. Springer Verlag, Berlin

Samtleben, C. (1977). Klappenwachstum und Entwicklung von Größenwachstum in Populationen von Mytilus edulis (L.) Meyniana 29: 51-69

Schaefer, R., Trutschler, K., Rumohr, H. (1985). Biometric studies on the bivalves Astarte elliptica, $A$. borealis and $A$ montagui in Kiel Bay (Western Baltic Sea). Helgoländer Meeresunters. 39: 245-253

Smetacek, V. (1985). The annual cycle of Kiel Bight plankton: a long term analysis. Estuaries 8: 145-157

Taylor, J. D., Kennedy, W. J., Hall, A. (1973). The shell structure and mineralogy of the bivalvia. 2. Lucinacea Clavagellacea. Conclusions. Bull. Br. Mus. nat. Hist. Zool. 22: 253-294

Theisen, B. F. (1973). The growth of Mytilus edulis L. (Bivalvia) from Disco and Thule District, Greenland. Ophelia 12: $59-77$

Thompson, I., Jones, D. S., Dreibelbis, D. (1980). Annual internal growth banding and life history of the ocean quahog Arctica islandica (Mollusca: Bivalvia). Mar. Biol. $57: 25-34$

Wada, K. (1961). Crystal growth of mulluscan shells. Bull. natl Pearl Res. Lab. 7: 703-828

Weigelt, M., Rumohr, H. (1986). Effects of wide-range oxygen depletion on benthic fauna und demersal fish in Kiel Bay 1982-1983. Meeresforschung 31: 124-136

Witt, U., Koske, P. H. Kuhlmann, D., Lenz, J., Nellen, W. (1981) Production of Nannochloris spec. (Chlorophyceae) in largescale outdoor tanks and its use as a food organism in marine aquaculture. Aquaculture 23: 171-181 